\title{
Upaya Meningkatkan Mutu Lembaga Pendidikan Islam melalui Sistem Akreditasi dalam Perspektif Total Quality Management (TQM) di SD Muhammadiyah Karangbendo Bantul
}

\author{
Luthfi Zihni Rahman \\ ${ }^{1}$ Universitas Islam Negeri (UIN) Sunan Kalijaga Yogyakarta \\ Izihnirahman2013@gmail.com
}

\begin{abstract}
Accreditation is an activity for evaluating the feasibility of a program in an education based on predetermined criteria. This accreditation is applied as an evaluation material and also controls the quality of education. However, even though the accreditation system has been developed and formulated in such a way, not many schools have been able to implement the existing instruments in the accreditation to improve the quality of their educational institutions. Many schools have not utilized the existing systems and instruments in accreditation optimally. Therefore, the implementation of accreditation in schools also requires an approach so that the process can run optimally. That approach is called by Total Quality Management (TQM). This research is a qualitative descriptive study. Data collection techniques through observation, documentation, and interviews. The results of this study found that accreditation in the TQM perspective contains the principles, among others: First, accreditation contains standards that are used as reference for implementation; Second, the school utilizes the assessment instruments that are in the accreditation to monitor the ongoing education services (monitoring and evaluation); Third, school accreditation is used to identify deficiencies in schools (deviations); Fourth, accreditation is used as a reference to continuously improve the quality of their schools.
\end{abstract}

Key Word: Quality of Education, School Accreditation, Total Quality Management (TQM).

\begin{abstract}
Abstrak
Akreditasi merupakan sebuah kegiatan penilaian kelayakan program dalam tiap satuan pendidikan berdasarkan kriteria yang telah ditetapkan. Sistem penilaian melalui akreditasi ini diberlakukan sebagai bahan untuk pengendalian mutu penyelenggaraan pendidikan. Sistem ini juga sebagai tolak ukur penyelenggaraan pendidikan di setiap jenjangnya. Akan tetapi, sekalipun sistem akreditasi telah diformulasi sedemikian rupa, namun pada pelaksanaannya belum banyak sekolah yang mampu memanfaatkan instrumen yang ada di dalamnya untuk meningkatkan mutu lembaga pendidikannya secara optimal. Karenanya, implementasi akreditasi di sekolah juga memerlukan sebuah pendekatan agar dalam prosesnya dapat berjalan secara maksimal. Pendekatan itu disebut dengan konsep Total Quality Management (TQM). Penelitian ini termasuk ke dalam penelitian deskriptif-kualitatif, dengan teknik pengumpulan data didapat melalui observasi, dokumentasi, serta wawancara.


Dari penelitian ini didapatkan bahwa akreditasi dalam perspektif TQM memuat prinsip-prinsip antara lain: Pertama, akreditasi memuat standar yang dijadikan acuan pelaksanaan; Kedua, sekolah memanfaatkan instrumen-instrumen penilaian yang ada di dalam akreditasi untuk memonitor pelayanan pendidikan yang berjalan (monitoring dan evaluasi); Ketiga, akreditasi sekolah digunakan untuk mengidentifikasi kekurangan yang ada di sekolah (deviasi); Keempat, akreditasi digunakan sebagai acuan untuk meningkatkan mutu sekolah mereka secara berkelanjutan.

Kata Kunci: Akreditasi Sekolah, Mutu Pendidikan, Total Quality Management (TQM).

\section{Pendahuluan}

Pendidikan nasional memiliki fungsi mengembangkan segenap potensi dan kemampuan, meningkatkan kualitas kehidupan, serta mengangkat martabat manusia dalam rangka mewujudkan tujuan negara yakni mencerdaskan kehidupan bangsanya. Untuk mencapai itu, para pemangku kebijakan pendidikan di Indonesia kemudian merumuskan tentang hal-hal apa saja yang dibutuhkan bagi peserta didik pada tiap tingkat satuan pendidikan.

Untuk mencapai tujuan itu, kemudian disusunlah seperangkat aturan yang menjelaskan bagaimana seharusnya sistem pendidikan di Indonesia berjalan. Rumusan itu selanjutnya dituangkan ke dalam Standar Nasional Pendidikan. Standar Nasional Pendidikan adalah seperangkat kriteria pelayanan minimal pelaksanaan pendidikan yang wajib dilaksanakan oleh setiap penyelenggara pendidikan di tiap dalam akreditasi sekolah juga berfungsi jenjangnya. ${ }^{1}$ Dalam pelaksanaannya, sebagai bahan monitoring untuk melihat

instrumen itu diperlukan sebagai bahan penilaian bagi setiap penyelenggara pendidikan. Instrumen penilaian itu kemudian disebut dengan akreditasi.

Dalam beberapa rujukan, akreditasi dapat diartikan sebagai sebuah kegiatan penilaian kelayakan program di tiap satuan pendidikan berdasarkan kriteria yang telah ditetapkan. $^{2}$ Akreditasi ini diberlakukan sebagai bahan penilaian dan juga pengendalian mutu penyelenggaraan pendidikan. Hal ini juga sebagai tolok ukur penyelenggaraan pendidikan di setiap jenjangya. Akreditasi ini pula yang dijadikan sebagai salah satu indikator untuk melihat sejauh mana kondisi riil yang ada di sekolah dengan standar nasional pendidikan yang sudah dirumuskan.

Sistem ini diterapkan di setiap sekolah untuk memacu agar sekolah semakin meningkatkan kapasitasnya. Penilaian di 
sejauh mana pencapaian kemajuan suatu sekolah. Akreditasi ini juga sebagai indikator untuk melihat mutu suatu lembaga pendidikan.

Agar pelaksanaan sistem akreditasi dapat berjalan secara terstruktur dan sistematis, perlulah ada sebuah badan yang secara khusus mengatur tentang sistem akreditasi ini yang kemudian dibentuk Badan Akreditasi Nasional (BAN). BAN memiliki tugas dan fungsi untuk melakukan evaluasi dan monitoring terhadap kelayakan penyelenggaraan pendidikan.

Di tingkat sekolah/madrasah, badan akreditasi ini disebut dengan Badan Akreditasi Nasional Sekolah/Madrasah (BAN S/M). BAN S/M merupakan suatu badan evaluasi independen yang bertugas memberikan ketetapan mengenai kelayakan program dan atau satuan pendidikan, mulai dari jenjang pendidikan dasar hingga menengah jalur formal dengan mengacu pada Standar Nasional Pendidikan yang sudah ditetapkan ${ }^{3}$. Sebuah badan atau lembaga yang bertugas untuk menilai sejauh mana kesesuaian antara nilai-nilai di dalam standar nasional pendidikan dengan praktik pendidikan yang berlangsung di lapangan. Diharapkan, dengan adanya badan atau lembaga khusus yang menangani akreditasi ini, penyelenggaraan pendidikan baik dari $\frac{3 \text { "Permendikbud59-2012BA N.Pdf," n.d. }}{\text { Jurnal Intelektual: Jurnal Pendidikan dan Studi Keislaman }}$ Volume 10, Nomor 2, Agustus 2020 tingkat pendidikan dasar, menengah, hingga pendidikan tinggi, dapat semakin meningkatkan kemampuannya.

Akan tetapi, sekalipun sistem akreditasi ini telah disusun sedemikian rupa, namun pada pelaksanaannya belum banyak sekolah yang mampu memanfaatkan intrumen yang ada dalam akreditasi tersebut untuk meningkatkan kapasitas lembaga pendidikannya. Fakta ini terlihat dari masih maraknya sekolah yang memenuhi instrumen akreditasi ketika hendak dilaksanakan kegiatan visitasi semata, dan kemudian kembali tidak berjalan optimal manakala proses visitasi telah usai dilaksanakan. Produktifitas sekolah menjadi meningkat ketika proses akreditasi akan dilakukan yakni dengan penyiapan dokumen sesuai dengan aturan yang ada, namun ketika akreditasi telah usai dilaksanakan produktifitas komponen akan kembali seperti semula ${ }^{4}$.

Sekolah terkesan memenuhi kelengkapan akreditasi sekadar untuk formalitas semata dan cenderung sebagai dan belum dilaksanakan secara serius dalam kehidupan sekolah sehari-hari. Karenanya, implementasi akreditasi di sekolah memerlukan sebuah pendekatan agar dalam prosesnya dapat berjalan secara optimal. Pendekatan itu disebut kemudian dikenal

4 Didin Asopwan, "Studi Tentang Akreditasi Dalam Meningkatkan Produktivitas Sekolah" 2, no. 2 (2018): 8. 
dengan konsep Total Quality Management (TQM) atau Manajemen Mutu Terpadu.

Secara sederhana, TQM dapat diartikan sebagai suatu pendekatan yang lazim digunakan untuk melakukan perbaikan secara terus menerus. Itu artinya, sebuah sistem yang didekati melalui konsep TQM tidak akan berhenti manakala sistem tersebut sudah berjalan saja, akan tetapi sistem tersebut haruslah memiliki peningkatan secara berkelanjutan. Diharapkan, sistem akreditasi yang dijalankan melalui pendekatan TQM dapat membawa manfaat yang lebih luas bagi sekolah. Secara jangka pendek, manfaat akreditasi sekolah ini dapat dirasakan dengan semakin meningkatnya ketertarikan calon siswa yang berniat mendaftar di sekolah tersebut. Sebab tidak bisa dipungkiri bahwa salah satu pertimbangan peserta didik memilih sekolah ialah dilihat dari status sekolahnya. Sedangkan secara jangka panjang, sistem akreditasi yang dilakukan secara tepat dan benar, diharapkan mampu memacu dan membentuk kualitas peserta didik yang unggul dan berdaya saing.

\section{Metode Penelitian}

Penelitian ini adalah penelitian deskriptif kualitatif, yakni jenis penelitian yang ditujukan untuk mendeskripsikan dan menganalisis suatu fenomena, peristiwa, aktifitas sosial, sikap, kepercayaan, persepsi,

pemikiran orang secara individu maupun kelompok ${ }^{5}$. Dalam hal ini, yang diteliti mengenai upaya peningkatan mutu lembaga pendidikan melalui sistem akreditasi dalam perspektif Total Quality Management (TQM). Penelitian ini dilakukan di SD Muhammadiyah Karangbendo, Kabupaten Bantul Daerah Istimewa Yogyakarta yang beralamat di Jalan Bulu, Jalan Karangbendo Kulon No. 2, Jaranan, Banguntapan, Kecamatan Banguntapan, Kabupaten Bantul, D.I. Yogyakarta. Dalam penelitian ini, yang menjadi sumber data ialah Kepala Sekolah SD Muhammadiyah Karangbendo yakni Sunardi, S.Pd dan wakil kepala bidang kurikulum, Witarko, M.Pd.

\section{Definisi Akreditasi}

Dalam beberapa literatur, akreditasi dimaknai sebagai suatu proses untuk memberikan penilaian terhadap kualitas menggunakan kriteria baku mutu yang sudah ditetapkan yang sifatnya terbuka. ${ }^{6}$ Melalui sistem akreditasi ini, setiap sekolah dinilai dan dilihat bagaimana praktik penyelenggaraan pendidikan yang berjalan, apakah sudah relevan dengan aturan dalam standar nasional atau belum. Akreditasi merupakan kegiatan penilaian untuk

\footnotetext{
5 Nana Syaodih Sukmadinata, Metode Penelitian Pendidikan (Bandung: PT. Remaja Rosdakarya, 2017).

6 "Pedoman Akreditasi Madrasah"

(Departemen Agama RI Direktorat Jenderal Kelembagaan Agama Islam, 2005).
} 
mengukur sejauh mana kelayakan program dalam satuan pendidikan. ${ }^{7}$ Kelayakan penyelenggaraan pendidikan ini dilihat dari sejauh mana lembaga pendidikan tersebut memenuhi atau bahkan melampaui standar standar nasional pendidikan. Akreditasi ini dilaksanakan oleh lembaga yang memiliki wewenang untuk memberikan penilaiannya terhadap proses pembelajaran yang berjalan di setiap satuan pendidikan, yakni dilakukan oleh BAN S/M.

Dalam proses akreditasi, yang menjadi objek penilaian adalah 8 (delapan) standar nasional pendidikan. Kedelapan standar itu antara lain:

a. Standar Isi

Standar isi memuat sekumpulan materi dan tingkat kompetensi yang digunakan untuk mengukur ketercapaian kompetensi lulusan di setiap jenjang pada setiap jenis pendidikan tertentu. Mutu standar isi berfokus pada muatan konten pelajaran yang terangkum dalam kurikulum. Standar isi disesuaikan dengan standar kompetensi lulusan yang hendak dicapai ${ }^{8}$.

b. Standar Kompetensi Lulusan

7 Aulia Ar Rakhman Awaludin, "Akreditasi Sekolah sebagai Suatu Upaya Penjaminan Mutu Pendidikan di Indonesia," SAP (Susunan Artikel Pendidikan) 2, no. 1 (August 9, 2017), https://doi.org/10.30998/sap.v2i1.1156.

${ }^{8}$ Engkoswara Engkoswara and Aan Komariah, Administrasi Pendidikan (Bandung: Alfabeta, 2012). Jurnal Intelektual: Jurnal Pendidikan dan Studi Keislaman Volume 10, Nomor 2, Agustus 2020
Standar kompetensi lulusan merupakan salah satu dari beberapa standar nasional pendidikan yang isinya termuat kualifikasi yang hendaknya dipenuhi oleh semua peserta didik, di setiap tingkat pendidikan yang isinya antara lain aspek sikap, pengetahuan serta keterampilan ${ }^{9}$. Standar ini dijadikan sebagai acuan untuk menentukan kelulusan peserta didik.

Dalam proses akreditasi, lulusan yang berprestasi baik secara akademik maupun non akademik dilakukan pendataan. Prestasi akademik berasal hasil tes kemampuan dalam bidang akademik. Sedangkan prestasi pada bidang non akademik dapat berupa prestasi di bidang olahraga, seni dan lain sebagainya. Semuanya masuk ke dalam sistem penilaian akreditasi.

c. Standar Proses

Standar proses menjelaskan mengenai standar pelaksanaan pembelajaran di suatu satuan pendidikan guna mencapai standar kompetensi lulusan. $^{10}$ Standar proses ini meliputi seluruh aktifitas pembelajaran yang dimulai dari perencanaan, pelaksanaan, sampai hasil pembelajaran.

9 Bahrul Hidayat and Suhendra Yusuf, Benchmark International Mutu Pendidikan (Jakarta: Bumi Aksara, 2010).

${ }^{10}$ Hidayat and Yusuf. 
Pembelajaran akan disebut efektif apabila materi ajar yang dipersiapkan dapat dipahami siswa. Karenanya, dalam proses akreditasi, akan dilakukan pengamatan antara lain kesesuaian antara rencana pembelajaran dengan visi misi sekolah, penyiapan sumber belajar dan alat peraga ${ }^{11}$.

d. Standar Sarana dan Prasaranana

Standar sarana dan prasarana merupakan pelayanan minimal yang berkaitan dengan fasilitas yang meliputi perabot, peralatan pendidikan, media, buku serta sumber bahan belajar lainnya. Sedangkan prasarana berkaitan dengan fasilitas tidak bergerak yang meliputi ruangan kelas, ruang kepala sekolah, ruang tata usaha, ruang guru, gedung perpustakaan, laboratorium, serta tempat ibadah. $^{12}$ Dalam standar sarpras ini, semua fasilitas yang ada di sekolah memiliki ukuran yang telah diatur. Pengaturan ukuran setiap fasilitas ini tentunya dengan mempertimbangkan aspek kenyamanan dan psikologis peserta didik. Itu semua dalam rangka agar pelaksanaan proses pembelajaran dapat dilaksanakan dengan aman dan nyaman. Sebagai contoh, dijelaskan dalam poin-poin kriteria dan perangkat akreditasi yang dirilis

${ }^{12}$ Hidayat and Yusuf, Benchmark International
Kementerian Pendidikan Dan Kebudayaan

Nomor 241/ P / 2019 diatur luas minimum lahan bangunan 1 lantai yakni sebesar $5299 \mathrm{~m}^{2}$, bangunan 2 lantai $2793 \mathrm{~m}^{2}$, dan bangunan lantai 3 lantai sebesar $1872 \mathrm{~m}^{2}$ jika sekolah tersebut memiliki rombngan belajar yang berkisar antara 7 sampai 9 kelas. ${ }^{13}$ Ukuran luas lahan minimum ini tentunya berbeda pada tiap jenjangnya.

e. Standar pengelolaan

Standar ini berisi kriteria-kriteria yang memuat aspek perencanaan, pelaksanaan, dan pengawasan penyelenggaraan pendidikan pada semua jenjang, baik dari tingkat kabupaten/kota hingga tingkat nasional agar penyelenggaraan pendidikan dapat tercapai secara efisien serta efektif ${ }^{14}$.

Berbekal standar pengelolaan ini, sekolah/madrasah diberikan panduan bahwa dalam penyusunan visi serta tujuan kelembagaan harus dimulai dari menampung seluruh aspirasi dan gagasan dari seluruh stakeholder sekolah dengan mempertimbangkan tujuan pendidikan nasional. Hal ini penting sebab visi sekolah merupakan sebuah cita-cita yang akan dicapai di masa yang akan datang. Dari visi besar tadi kemudian dijabarkan

13 "Salinan Keputusan Menteri Pendidikan Dan Kebudayaan Republik Indonesia Nomor 241 / P / 2019 Tentang Kriteria Dan Perangkat Akreditasi.” (Menteri Pendidikan dan kebudayaan, 2019). 14 "PP-No-13-Tahun-2015.Pdf," n.d. 
secara terperinci ke dalam misi. Misi inilah yang memberikan arah untuk ketercapaian visi. Setelah itu, aspirasi tersebut diputuskan melalui rapat yang dipimpin kepala sekolah. Gagasan yang telah diputuskan tersebut disosialisasikan ke seluruh warga sekolah serta pemangku kepentingan yang ada. Terakhir, dilakukan peninjauan kembali secara berkala disesuaikan dengan perkembangan sekolah.

Dalam pelaksanaan visitasi, semua hal yang berkaitan dengan standar pengelolaan harus dibuktikan dengan dokumen-dokumen terkait antara lain dokumen visi, misi, serta tujuan, dan daftar hadir kegiatan perumusan instrumen penting tersebut. Selanjutnya tim visitasi melakukan observasi langsung ke sekolah untuk melihat ketersediaan bukti fisik dokumen yang diperlukan. Terakhir, tim visitasi melakukan wawancara dengan pihak-pihak yang terlibat dalam perumusan dan sosialiasi visi tersebut. ${ }^{15}$

f. Standar Pembiayaan

Standar pembiayaan memuat kriteria dalam yang berisi komponen dan besarnya biaya operasional pendidikan yang dibutuhkan dalam kurun waktu satu

\footnotetext{
15 "Salinan Keputusan Mendikbud RI No. 241/
}

tahun. $^{16}$ Ruang lingkup pembahasan dalam standar ini antara lain: rencana kerja anggaran terkait pengembangan sarana dan prasarana pendidikan, pengembangan pendidik, pengembangan tenaga kependidikan, serta modal kerja ${ }^{17}$.

g. Standar Penilaian

Standar penilaian adalah standar yang berkaitan dengan mekanisme, prosedur, dan instrumen penilaian hasil belajar. $^{18}$ Pada standar ini, pendidik diberikan pedoman dalam memberikan penilaian terhadap pencapaian peserta didik. Seorang pendidik tidak bisa memberikan penilaian kepada peserta didik secara sembarangan, melainkan dilakukan secara profesional dengan memerhatikan prinsip-prinsip antara lain Pertama dilakukan dengan sahih atau benar, artinya apa yang dinilai itulah fakta yang sebenarnya. Kedua objektif, yakni sesuai dengan pencapaian peserta didik. Ketiga yaitu adil, tidak membeda-bedakan peserta didik yang satu dengan yang lain. Tidak menguntungkan peserta didik berdasar berlatar belakang agama, suku, budaya, atau adat istiadat. Prinsip keempat yaitu terbuka, artinya poin dan item yang menjadi penilaian dapat diketahui oleh peserta didik. Prinsip yang kelima

16 "PP-No-13-Tahun-2015.Pdf."

17 "Salinan Keputusan Mendikbud RI No. 241/ P/ 2019." 
akuntabel atau dapat

dipertanggungjawabkan ${ }^{19}$.

h. Standar Pendidik dan Tenaga Kependidikan

Standar ini memuat seperangkat kriteria mengenai pendidikan pra-jabatan dan kelayakan fisik maupun mental, serta pendidikan dalam jabatan. $^{20}$ Dalam hal ini, pendidik maupun tenaga kependidikan yang menjalankan tugas di sebuah lembaga pendidikan, harus memiliki kompetensi yang sesuai dengan bidang keahliannya. Hal ini dimaksudkan agar peserta didik mendapatkan jaminan pelayanan pendidikan secara profesional.

\section{Prinsip-Prinsip Akreditasi}

Dalam penilaian akreditasi ini, ada beberapa prinsip yang harus diperhatikan, agar proses yang dijalani sesuai dengan tujuan akreditasi yakni meningkatkan mutu pendidikan. Prinsip tersebut antara lain ${ }^{21}$ :

a. Objektif: Pada prinsipnya, proses akreditasi ini merupakan suatu tolok ukur untuk melihat bagaimana sebuah lembaga pendidikan dapat berjalan. Karenanya, penilaian harus dilakukan secara objektif dan sesuai dengan kondisi yang sebenarnya untuk

19 "Salinan Keputusan Mendikbud RI No. 241/ P/ 2019."

20 "PP-No-13-Tahun-2015.Pdf."

${ }^{21}$ Draf Pedoman Akreditasi Sekolah Madrasah 2018 (Jakarta: Badan Akreditasi Sekolah/Madrasah, mendapatkan gambaran tentang perkembangan lembaga pendidikan.

b. Komprehensif: penilaian dalam akreditasi dilakukan secara keseluruhan, tidak terbatas pada aspekaspek tertentu saja agar mendapatkan infomasi sekolah secara utuh dan menyeluruh.

c. Adil: semua lembaga pendidikan, baik sekolah ataupun madrasah mendapatkan pelayanan penilaian yang sama, sesuai dengan kondisi yang sebenarnya. Hal itu dilakukan tanpa memandang kultur sosial-budaya, keyakinan, ras, maupun status sekolah negeri maupun swasta.

d. Transparan: setiap sekolah yang bersiap untuk dilakukan akreditasi memiliki hak akses keterbukaan informasi yang berkaitan tentang kriteria, jadwal, sistem penilaian, persyaratan, dan hal-hal yang harus dipenuhi selama proses akreditasi.

e. Akuntabel: proses maupun hasil selama akreditasi dapat dipertanggungjawabkan.

f. Profesional: akreditasi dilakukan secara hati-hati oleh pihak-pihak yang memiliki kompetensi di bidangnya, sehingga proses dan hasil yang didapatkan nantinya dapat dijadikan sebagai acuan dan dasar perbaikan. 


\section{Hasil Penelitian dan Pembahasan}

Sebagaimana telah dijelaskan pada pembahasan sebelumnya, akreditasi merupakan sebuah instrumen untuk mengukur sejauh mana praktik pendidikan yang sudah berjalan, memiliki kesesuaian dengan apa yang menjadi tujuan ideal diselenggarakannya pendidikan. Melalui kegiatan akreditasi dengan seperangkat mekanisme di dalamnya ini, diharapkan dapat menjadi pemacu dan menciptakan kultur yang kondusif bagi perkembangan sebuah lembaga pendidikan. Selain itu, dapat juga dijadikan sebagai arahan untuk melakukan penjaminan mutu lembaga pendidikan secara berkelanjutan, serta terus berupaya mencapai kualitas yang sudah direncanakan. Secara lebih spesifik, fungsi akreditasi sekolah/madrasah dapat dijabarkan sebagai berikut ${ }^{22}$ :

\section{a. Perlindungan Masyarakat (Quality Assurance)}

Masyarakat mendapatkan jaminan mengenai kualitas penyelenggaraan pendidikan yang akan dipilihnya. Dengan demikian, hal ini akan menghindarkan pengguna layanan pendidikan dari adanya praktik yang tidak bertanggungjawab. Hal ini diperkuat dengan sebuah penelitian yang dilakukan oleh Supriyatno dkk. di sebuah sekolah dasar di Kabupaten
Purworejo, Jawa Tengah. Hasil penelitian itu menunjukkan adanya peningkatan jumlah siswa di setiap tahun ajaran baru setelah sekolah yang diteliti mendapatkan akreditasi yang baik. $^{23}$ Dalam hal ini, akreditasi berperan mengubah pandangan masyarakat untuk memilih sekolah bagi anak-anak mereka. Dengan adanya penilaian dalam akreditasi ini, pelanggan pendidikan mendapatkan jaminan bahwa penyelenggaraan pendidikan tempat di mana mereka berinvestasi, dikelola secara serius dengan komponen yang berkualitas. Hal ini pula dapat dijadikan sebagai bahan pertimbangan bagi orang tua calon siswa untuk menyekolahkan anak-anak mereka di sekolah tersebut. Di SD Muhammadiyah Karangbendo, manfaat akreditasi dirasakan dengan semakin meningkatnya antusiasme calon siswa yang mendaftar di sekolah ini setiap tahunnya. Jika dulunya sekolah ini selalu kekurangan siswa, beberapa tahun belakangan, setelah akreditasi sekolah mendapatkan nilai $\mathrm{A}$, antusiasme peminat sekolah meningkat, bahkan tidak semua siswa diterima. Di samping itu, akreditasi yang ada saat ini juga sebagai bentuk legalitas atau pengakuan sebagai pelayanan pendidikan yang sudah sesuai

23 Eko Supriyanto, "Pengelolaan Akreditasi Sekolah (Studi Situs Sd Negeri 2 Mranti Kecamatan Purworejo Kabupaten Purworejo)," Jurnal Penelitian Humaniora, 2, 14 (2013): 9. 
standar yang telah ditetapkan pemerintah.

Hal ini tentunya menambahkan

kepercayaan bagi masyarakat, khususnya pengguna layanan pendidikan.

b. Pengendalian Mutu (Quality Control)

Pengendalian mutu ini dimaksudkan agar sebuah lembaga mampu mendeteksi adanya penyimpangan antara kenyataan yang terjadi di lapangan, dengan standar yang sudah ditetapkan. ${ }^{24}$ Lembaga pendidikan dapat mengidentifikasi kekuatan dan kelemahan yang mereka miliki. Berbekal hasil identifikasi tersebut, dapat dijadikan sebagai sebuah bahan untuk melakukan evaluasi, serta merencanakan program pengembangan dan penguatan lembaga secara berkesinambungan. Melalui sistem penilaian yang terdapat dalam akreditasi, setiap sekolah atau madrasah dapat melakukan analisis kekurangan dan kelebihan penyelenggaraan pendidikan yang berjalan di lembaga pendidikannya. Dengan itu, kekurangan yang ada di lembaga pendidikan tersebut dapat dibenahi, serta kelebihan yang sudah ada dapat dijaga secara berkesinambungan bahkan ditingkatkan lagi. Berbekal akreditasi, SD Muhammadiyah melakukan

24 Emilia Nur Chasanah Sholihin, Ibrahim Bafadal, and Asep Sunandar, "Pengelolaan Persiapan Akreditasi Sekolah," Jurnal Administrasi dan Manajemen Pendidikan 1, no. 2 (May 28, 2018): 17178, https://doi.org/10.17977/um027v1i22018p171. pengendalian mutu dengan cara melengkapi kekurangan-kekurangan yang ditemukan di sekolah. Apalagi, instrumen akreditasi yang senantiasa dilakukan pengembangan dari waktu ke waktu "memaksa" sekolah untuk senantiasa melakukan perbaikan layanan pendidikan, sesuai tuntutan waktu dan zaman. Akreditasi sekolah juga dapat berperan sebagai pengingat agar seluruh warga sekolah tidak lengah dalam memberikan layanan pendidikan yang baik.

c. Pengembangan Mutu (Quality Improvement)

Lembaga pendidikan semakin terpacu dan termotivasi untuk selalu mempertahankan kualitas lembaganya, yang dibarengi dengan melakukan inovasi-inovasi pengembangan serta berupaya secara maksimal untuk menyempurnakan dari berbagai kekurangan. Tentunya, hal ini dapat dilakukan dengan mengacu pada standar yang ada. Standar tersebut terjabarkan secara detail dan terperinci di dalam instrumen akreditasi. Melaui format penilaian akreditasi ini, sekolah ataupun madrasah dapat mengidentifikasi bagianbagian mana di dalam lembaga pendidikannya yang dirasa perlu untuk dipertahankan dan juga dilakukan pengembangan agar kualitas atau mutu lembaga dapat terus meningkat. Secara 
teknis, pengembangan mutu sekolah melalui akreditasi dilakukan dengan cara melengkapi hal-hal yang belum ada. Menjelang akreditasi biasanya terdapat petunjuk teknis (juknis) akreditasi, dari situ sekolah bisa mengontrol apa-apa yang belum ada di sekolah. dengan adanya instrumen akreditasi menjadi dorongan bagi sekolah untuk mengembangkan atau melengkapi fasilitas-fasilitas yang belum ada tersebut.

\section{Hasil Akreditasi}

a. Acuan dalam rangka meningkatkan mutu dan perencanaan pengembangan lembaga. Sejalan dengan itu, Suryana sebagaimana dikutip dalam Uum mengatakan bahwa akreditasi juga merupakan alat regulasi diri (self regulation), yakni untuk mengukur kekuatan dan kelemahan diri. ${ }^{25}$ Akreditasi ini dilakukan sebagai upaya terstruktur dan sistematis untuk memperbaiki kualitas lembaga pendidikan secara berkelanjutan.

b. Timbal balik dalam usaha memberdayakan dan mengembangkan kinerja warga sekolah dalam rangka menerapkan visi, misi, tujuan, sasaran, strategi,

25 Uum Gatot Karyanto and Arif Rahman, "Implikasi Akreditasi Sekolah terhadap Peningkatan Mutu Tata Kelola Smk Negeri 1 Oku” 7, no. 2 (2015): dan program sekolah/madrasah. Tindak lanjut hasil penilaian akreditasi ini kemudian dilaksanakan melalui pelaksanaan yang serius di dalam kehidupan warga sekolah sehari-hari. Misalnya, dalam proses pembelajaran, guruguru menjalankan kegiatan belajar mengajar mulai dari perencanaan, proses, hingga evaluasi dengan mengacu pada petunjuk teknis proses pembelajaran, sebagaimana tertuang di dalam instrumen akreditasi. Seluruh warga sekolah berusaha semaksimal mungkin menyelenggarakan pendidikan sesuai dengan standar nasional pendidikan yang telah ditetapkan.

c. Motivasi agar lembaga pendidikan terus menerus meningkatkan kualitas pendidikan secara bertahap, terstruktur, dan kompetitif baik dari tingkat kabupaten/kota, bahkan hingga internasional. Dengan hasil ini, sekolah dapat mengukur dan menilai diri sendiri, sudah sejauh mana kualitas lembaga pendidikan mereka. Ketercapaian yang baik dalam akreditasi dijalankan secara serius dalam kehidupan sekolah sehari-hari, dalam proses pembelajaran. 
d. Bahan informasi bagi sekolah. Pertama, bahan informasi yang berguna untuk mendapatkan dukungan dari stakeholder pendidikan yakni pemerintah, masyarakat maupun pihak-pihak lain, baik dalam hal profesionalisme, moral, tenaga, serta dana. Tentunya, mereka yang memiliki akreditasi yang lebih tinggi, relatif lebih mudah mendapatkan akses dari mana saja. Kedua, dari lingkungan internal sekolah sendiri. Akreditasi menjadi sumber informasi yang up to date. Terkadang, dalam proses akreditasi ini, tidak jarang sekolah mendapatkan informasi-informasi baru mengenai pelaksanaan pendidikan. Hal ini sebagai bentuk sistem akreditasi yang semakin berkembang menyesuaikan perkembangan waktu dan zaman.

e. Acuan bagi pemangku kebijakan terkait untuk dijadikan bahan pertimbangan sebagai penyelenggara ujian nasional. Hal tersebut mengingat sekolah yang memiliki akreditasi lebih tinggi tentunya diimbangi dengan fasilitas yang lebih siap dan memadai untuk menyelenggarakan ujian nasional.
2. Akreditasi Dalam Perspektif Total Quality Management (TQM) di SD Muhammadiyah Karangbendo Bantul Sebagaimana dijelaskan pada pembahasan sebelumnya, bahwa proses akreditasi sekolah ini merupakan seperangkat upaya yang dipersiapkan untuk meningkatkan mutu sebuah lembaga pendidikan. Akreditasi sekolah haruslah dimaknai sebagai suatu upaya untuk meningkatkan mutu, kinerja, dan produktivitas satuan pendidikan. $^{26}$ Hal itu dibuktikan dengan beberapa item di dalam akreditasi sekolah sudah sesuai dengan prinsip-prinsip yang ada pada Total Quality Management (TQM). Prinsip TQM yang pertama yakni sebuah produk atau jasa harus mempunyai sebuah standar. Akreditasi sekolah sendiri memiliki sebuah standar penilaian yang terjabarkan dalam 8 Standar Nasional Pendidikan (SNP). Standar ini dijadikan sebagai sebuah acuan pelaksanaan penyelenggaraan pendidikan di SD Muhammadiyah Karangbendo.

Prinsip yang kedua yakni monitoring dan evaluasi. Proses

26 Marjuki Marjuki, Djemari Mardapi, and Badrun Kartowagiran, "Pengembangan model akreditasi sekolah menengah atas /madrasah aliyah (SMA/MA)," Jurnal Penelitian dan Evaluasi Pendidikan 22, no. 1 (June 26, 2018): 105, https://doi.org/10.21831/pep.v22i1.9860. 
akreditasi sekolah ini dijadikan sebagai bahan monitoring dan evaluasi bagi setiap lembaga pendidikan.

Dengannya, lembaga pendidikan dapat mengukur sudah sejauh mana kualitas penyelenggaraan pendidikan mereka, apakah sudah berhasil mencapai SNP atau bahkan melampaui. Bagi SD Muhammadiyah Karangbendo, pihak sekolah memanfaatkan instrumeninstrumen penilaian yang ada di dalam akreditasi untuk memonitor pelayanan pendidikan yang berjalan di sekolah mereka. Berbekal akreditasi ini, sekolah dapat mengidentifikasi bagian mana saja di sekolah mereka yang masih belum memenuhi standar yang sudah ditetapkan. Kekurangan yang masih ada pada saat itu juga dilengkapi.

Prinsip yang ketiga yakni identifikasi penyimpangan (deviasi). Sebagaimana kia ketahui bahwa akreditasi sekolah ini merupakan sebuah instrumen yang disusun untuk meningkatkan mutu suatu sekolah. Akan tetapi pada pelaksanaannya bukan berarti tidak ditemukan celah. Menurut Witarko, kekurangan dalam akreditasi ini terlihat dari ketidaksesuaian antara standar pelayanan minimal (SPM) dengan akreditasi. Contohnya, dalam aturan
SPM, luas ruang kelas minimum bagi sekolah/madrasah ialah seluas 6x7, sedangkan dalam akreditasi yang dinilai ialah $7 x 8$. Hal ini tentunya menyulitkan bagi sekolah untuk menyediakan prasarana fisik bangunan yang tentunya tidak mungkin bisa dilakukan dengan cepat.

Namun, di samping itu, dengan seperangkat penilaian yang ada dalam akreditasi ini, sekolah bisa menggunakan instrumen dalam akreditasi ini untuk mengidentifikasi bagian-bagian mana saja di sekolahnya yang dirasa masih kurang atau belum memenuhi standar yang sudah ditetapkan. Sekolah tentunya dapat menjadikan akreditasi sebagai intrumen yang dapat digunakan sebagai identifikasi kekurangan-kekurangan di sekolah mereka. Kekurangan yang ada tersebut nantinya bisa dilakukan perbaikan. Di SD Muhammadiyah Karangbendo, untuk memperbaiki kekurangan dalam penilaian akreditasi, khususnya dalam bidang sarana dan prasarana dilakukan melalui pembelian barang-barang yang sekiranya dapat dibeli jadi, maka dibeli pada saat itu juga. Selain itu, keterlibatan secara aktif oleh seluruh warga sekolah untuk melengkapi dan memperbaiki kekurangan apa saja yang masih bisa 
diperbaiki sesuai dengan instrumen Kesimpulan

penilaian akreditasi.

Prinsip yang keempat yakni peningkatan berkelanjutan. Sekolah bisa menggunakan hasil penilaian di dalam akreditasi tadi sebagai acuan untuk meningkatkan mutu sekolah mereka secara berkelanjutan. Hasil akreditasi tadi dapat digunakan untuk menjaga kualitas penyelenggaraan pendidikan (proses), atau sebagai dasar sebelum melakukan inovasi-inovasi agar mendapatkan hasil (output) yang berkualitas pula. Implementasinya di SD Muhammadiyah Karangbendo, standarisasi akreditasi dijadikan acuan dalam operasional sekolah sehari-hari. Kalau ada hal yang kurang maka kekurangan tersebut dipenuhi, sedangkan kalau ada hal yang lebih, maka kelebihan itu diidentifikasi sebagai keunggulan yang dimiliki sekolah. "Kalau yang kurang dipenuhi, kalau yang lebih dari minimal standar, itu menjadi satu keunggulan yang dimiliki sekolah, dan dijadikan sebagai sarana promosi sekolah. Kelebihan tersebut tidak dipangkas, justru dijadikan sebagai program unggulan sekolah.”
Akreditasi sekolah merupakan salah satu upaya yang dipersiapkan oleh pemerintah untuk meningkatkan mutu pendidikan. Instrumen-instrumen penilaian di dalamnya sendiri mengalami berbagai macam perubahan dan senantiasa dilakukan pengembangan yang disesuaikan dengan perubahan kondisi zaman serta kebutuhan masyarakat saat ini.

Akreditasi sekolah dapat dimaknai dengan dua hal, pertama akreditasi sekolah sebagai sebuah proses dan akreditasi sekolah sebagai sebuah hasil. Akreditasi sekolah sebagai sebuah proses dimaknai sebagai kerangka acuan bagi setiap lembaga pendidikan untuk menilai dan mengevaluasi lembaga pendidikannya. Item-item yang termuat dalam penilaian akreditasi tersebut digunakan untuk memperbaiki kualias penyelenggaraan pendidikan apabila masih ditemui berbagai permasalahan.

Sedangkan, akreditasi sebagai sebuah hasil merupakan sertifikat penilaian yang dikeluarkan oleh pihak yang memiliki wewenang, dalam hal ini diberikan oleh BAN S/M sebagai bentuk pengakuan bagi lembaga pendidikan tersebut. Nantinya, sertifikat pengakuan tersebut dapat berguna bagi pelanggan jasa pendidikan agar merasa mendapatkan jaminan pelayanan pendidikan dengan sebaik-baiknya. 


\section{Daftar Pustaka}

Asopwan, Didin. "Studi Tentang Akreditasi Dalam Meningkatkan Produktivitas Sekolah" 2, no. 2 (2018): 8 .

Awaludin, Aulia Ar Rakhman. "Akreditasi Sekolah sebagai Suatu Upaya Penjaminan Mutu Pendidikan di Indonesia." SAP (Susunan Artikel Pendidikan) 2, no. 1 (August 9, 2017). https://doi.org/10.30998/sap.v2i1.1156.

Draf Pedoman Akreditasi Sekolah Madrasah 2018. Jakarta: Badan Akreditasi Sekolah/Madrasah, 2018.

Engkoswara, Engkoswara, and Aan Komariah. Administrasi Pendidikan. Bandung: Alfabeta, 2012.

Hidayat, Bahrul, and Suhendra Yusuf. Benchmark International Mutu Pendidikan. Jakarta: Bumi Aksara, 2010

Karyanto, Uum Gatot, and Arif Rahman. "Implikasi Akreditasi Sekolah terhadap Peningkatan Mutu Tata Kelola Smk Negeri 1 Oku" 7, no. 2 (2015): 15.

Marjuki, Marjuki, Djemari Mardapi, and Badrun Kartowagiran. "Pengembangan model akreditasi sekolah menengah atas /madrasah aliyah (SMA/MA)." Jurnal Penelitian dan Evaluasi Pendidikan 22, no. 1 (June 26, 2018): 105. https://doi.org/10.21831/pep.v22i1.986 0.

$\begin{array}{llrr}\text { "Pedoman Akreditasi } & & \text { Madrasah." } \\ \text { Departemen Agama } & \text { RI } \begin{array}{r}\text { Direktorat } \\ \text { Jenderal Kelembagaan }\end{array} & \text { Agama Islam, } \\ \text { 2005. } & & & \end{array}$

"Permendikbud59-2012BAN.Pdf," n.d.

“PP-No-13-Tahun-2015.Pdf," n.d.
"Salinan Keputusan Menteri Pendidikan Dan Kebudayaan Republik Indonesia Nomor 241 / P / 2019 Tentang Kriteria Dan Perangkat Akreditasi." Menteri Pendidikan dan kebudayaan, 2019.

Sholihin, Emilia Nur Chasanah, Ibrahim Bafadal, and Asep Sunandar. "Pengelolaan Persiapan Akreditasi Sekolah." Jurnal Administrasi dan Manajemen Pendidikan 1, no. 2 (May 28, 2018): 171-78. https://doi.org/10.17977/um027v1i22018p17 1.

Supriyanto, Eko. "Pengelolaan Akreditasi Sekolah (Studi Situs SD Negeri 2 Mranti Kecamatan Purworejo Kabupaten Purworejo)." Jurnal Penelitian Humaniora, 2, 14 (2013): 9.

Syaodih Sukmadinata, Nana. Metode Penelitian Pendidikan. Bandung: PT. Remaja Rosdakarya, 2017.

"UU20-2003Sisdiknas.Pdf," n.d. 